\title{
Cognitive Impairment in End Stage Renal Disease Patients Undergoing Hemodialysis: Markers and Risk Factors
}

\author{
Piotr Olczyk (D), Mariusz Kusztal *(D), Tomasz Gołębiowski (D), Krzysztof Letachowicz (D) and Magdalena Krajewska \\ Department of Nephrology and Transplantation Medicine, Wroclaw Medical University, Borowska 213, \\ 50-556 Wrocław, Poland; ol.piotr1994@gmail.com (P.O.); tomasz.golebiowski@umw.edu.pl (T.G.); \\ krzysztof.letachowicz@umw.edu.pl (K.L.); magdalena.krajewska@umw.edu.pl (M.K.) \\ * Correspondence: mariusz.kusztal@umw.edu.pl; Tel.: +48-71733-2500
}

check for updates

Citation: Olczyk, P.; Kusztal, M.; Gołębiowski, T.; Letachowicz, K.; Krajewska, M. Cognitive Impairment in End Stage Renal Disease Patients Undergoing Hemodialysis: Markers and Risk Factors. Int. J. Environ. Res. Public Health 2022, 19, 2389. https:// doi.org/10.3390/ijerph19042389

Received: 19 December 2021 Accepted: 15 February 2022 Published: 18 February 2022

Publisher's Note: MDPI stays neutral with regard to jurisdictional claims in published maps and institutional affiliations.

Copyright: (C) 2022 by the authors. Licensee MDPI, Basel, Switzerland. This article is an open access article distributed under the terms and conditions of the Creative Commons Attribution (CC BY) license (https:// creativecommons.org/licenses/by/ $4.0 /)$.

\begin{abstract}
Background: Cognitive impairment (CI) is common in chronic kidney disease (CKD) and patients treated with hemodialysis. (2) Methods: The systematic review was prepared following the PRISMA statement (2013). The biomedical electronic databases MEDLINE and SCOPUS were searched. (3) Results: out of 1093 studies, only 30, which met problem and population criteria, were included in this review. The risk factors for CI can be divided into three groups: traditional risk factors (present in the general population), factors related to dialysis sessions, and nontraditional risk factors occurring more frequently in the HD group. (4) Conclusions: the methods of counteracting CI effective in the general population should also be effective in HD patients. However, there is a need to develop unique anti-CI approaches targeting specific HD risk factors, i.e., modified hemodialysis parameters stabilizing cerebral saturation and blood flow.
\end{abstract}

Keywords: renal replacement therapy; cognition; dementia; cardiovascular; dialysis; cerebral blood flow; brain saturation

\section{Introduction}

The incidence of end-stage renal disease (ESRD) requiring dialysis continued to rise and reached 554,038 in 2018 in the US. In 2018, 124,500 new ESRD cases were registered, compared to 131,636 in the previous year. The number of dialysis patients on the kidney transplant waiting list as of 31 December 2017, was 75,745 applicants, $85 \%$ of whom were waiting for their first kidney transplant. Spending on ESRD patients was USD 35.9 billion, which is $7.2 \%$ of all claims paid by Medicare on the service fee system [1]. This group is exposed to many hemodialysis side effects, such as progressive cardiovascular damage, calcium-phosphorus disorders, accelerated dementia, and cognitive decline. A significant deterioration of cognitive function in hemodialysis patients is also observed in non-elderly patients in numerous studies [2,3], which was also identified as an independent risk factor increasing mortality [4]. Cognitive impairment is common in chronic kidney disease and in patients treated with dialysis. Patients treated with hemodialysis perform worse than the general population on tests of global cognition, attention and orientation, concept formation and reasoning, construction and motor performance, executive functioning, language, and memory [2]. During hemodialysis, there are significant changes in the circulatory system. The reason for this is the loss of water, both in the ultrafiltration process and from migration to tissues from blood vessels. This leads to a decrease in blood volume and an increase in its density and viscosity. Peripheral resistance is also increasing. All of these changes cause impairment of tissue blood supply, including the central nervous system [5]. A systematic review of risk factors in this group of patients was prepared, taking into account the importance of cognitive impairment in hemodialysis patients. 


\section{Materials and Methods}

The systematic review was created using the "Preferred Reporting Items for Systematic Reviews and Meta-Analysis" (PRISMA, 2013). Furthermore, with the assistance of a professional health science librarian at the authors' university, biomedical electronic databases such as SCOPUS and MEDLINE were searched. Figure 1 depicts a flow diagram outlining the literature search strategies. To identify relevant search terms, preliminary database searches were performed with the search terms (cognitive or cognition or cognitive decline or cognitive impairment) AND (hemodialysis). The systematic review includes works published 10 years prior to 30 April 2021. The PICO algorithm was used to establish the criteria for including papers in the review. The following standards were devised: $\mathrm{P}$ (population)—adult hemodialysis patient with cognitive impairment; I (Intervention) there is no intervention; $\mathrm{C}$ (Comparison) —with a healthy population or a hemodialysis patient who does not have cognitive impairment; $\mathrm{O}$ (Outcome)-the statistical relationship that exists between cognitive decline and a specific factor. The terms "Alzheimer's disease" and "dementia" were not included as search terms because the current study focused on cognitive impairment in hemodialysis patients, which is mostly a mild cognitive disorder and is thought to differ from dementia or Alzheimer's disease in terms of risk factors or correlates. Excluded studies met the following criteria: (1) animal model studies; (2) studies with insufficient statistical data; (3) review studies; (4) abstract-only studies; (5) qualitative studies; (6) case reports; or (7) gray literature studies (theses, conference proceedings, grant or technical reports). Two scientists searched the databases, and an experienced work supervisor clarified any doubts about whether a particular piece of work was included in the review.

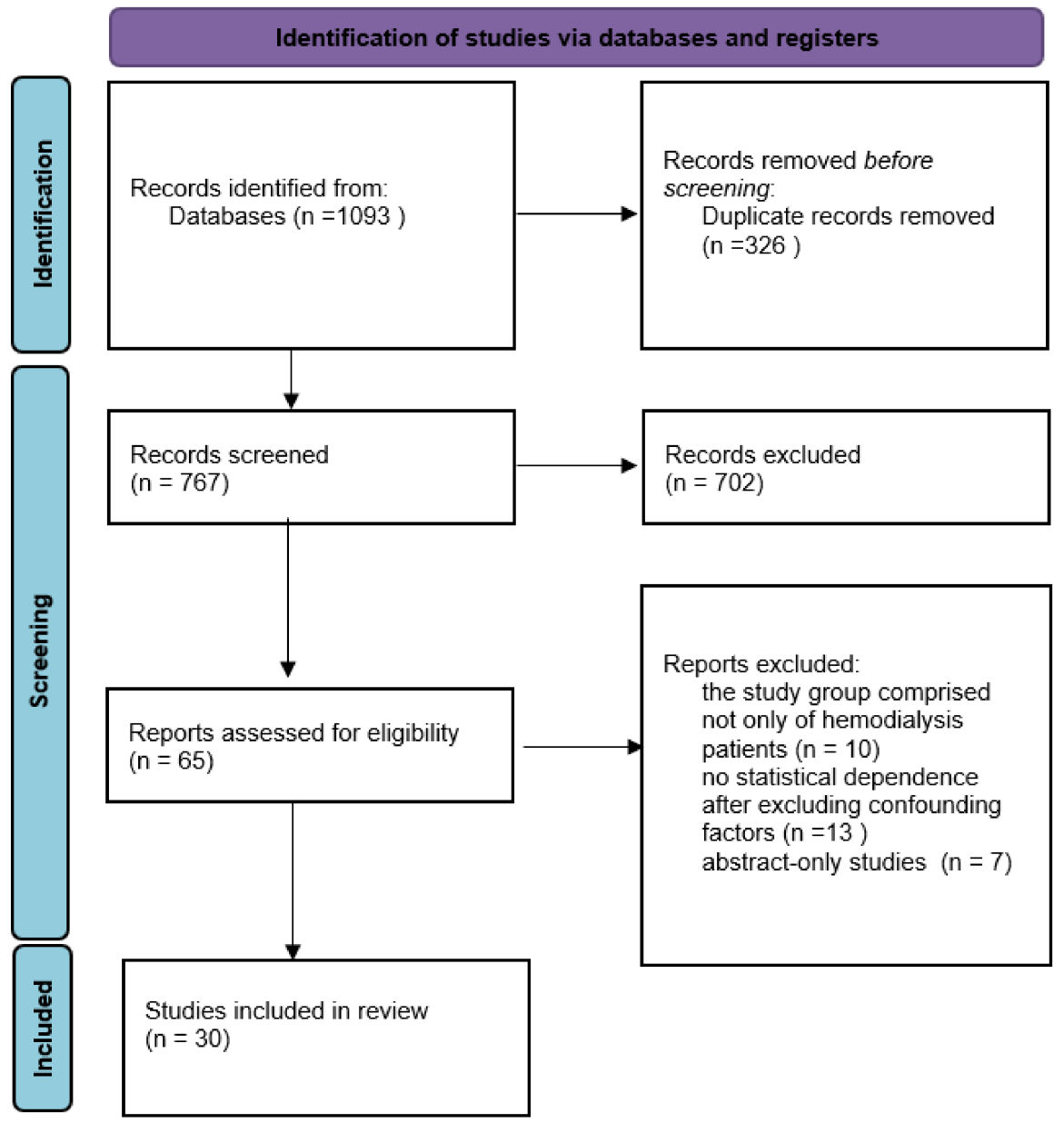

Figure 1. A flow diagram outlining the literature search strategies. 


\section{Results}

Findings from identified studies were classified as markers of the inflammatory process and cell damage, markers of uremic toxins, disorders associated with ESRD, systemic cardiovascular risk factors, fluctuations in cerebral blood flow associated with dialysis sessions, and unclassified lifestyle and socioeconomic factors.

\subsection{Markers Related to the Inflammatory Process and Cell Damage}

Table 1 displays markers associated with the inflammatory process or cell damage in dialysis patients.

S100B is one of the markers associated with CI in HD patients. It is a calcium-binding protein that is found in Schwann cells, astrocytes, and glial cells. Multiple logistic regression analyses in the cited study revealed that serum S100B level was a statistically significant independent predictor of CI [6].

The OPG/RANK/RANKL system is important in skeletal health and bone biology, as well as in other tissues such as the lungs, brain, and heart [7,8]. It is also linked to the pathophysiology of cardiovascular disorders with a vascular component, such as diabetes and atherosclerosis [9]. In HD patients, a link was discovered between serum log-transformed RANKL levels and cognitive function tests (MoCA and CASI) [10].

Many studies conducted in general population suggest an association between cognitive functions and markers of endothelial damage [11]. Endothelial cells express, among others, intracellular adhesion molecule 1 (ICAM-1), vascular cell adhesion molecule 1 (VCAM1) or Syndecan-1. Syndecan-1, ICAM-1, and angiopoietin-2 (AGPT2) were found to be associated with CI in a study by Freire de Medeiros [12]. However, AGPT2 was found to have the strongest association with cognitive function $(\mathrm{r}=-0.316, p=0.001)$. In stressed endothelial cells, angiopoietin-2 acts as an autocrine protective factor. High AGPT2 levels in CKD patients (particularly in G5) are associated with vascular stress due to abnormal fluid status and play a role in fluid distribution and accumulation.

Because CI is associated with cardiovascular mortality and vascular factors play a significant role in neurodegenerative disease, more research with endothelial damage markers is warranted.

The following study looked at the relationship between brain-derived neurotrophic factor (BDNF), inflammatory cytokines (TNF-, IL-6), fibroblast growth factor (FGF)-23 and its co-receptor -klotho, and platelet (PLT) count in HD patients. TNF-, BDNF, and blood PLT levels, as well as IL-6, were found to have statistically significant relationships [13]. BDNF is a protein that is distributed and synthesized in the nervous system (CNS). Furthermore, it is important in the differentiation, survival, and growth of neurons during CNS development $[14,15]$. Furthermore, inflammatory cytokines play an important role in the pathogenesis of hemodialysis-related side effects associated with brain diseases [16-18]. This study found that IL-6 and TNF- levels increased significantly in HD patients. Their levels differed significantly between the control and MCD groups.

According to the research, insulin-like growth factor-1 (IGF-1) can be used as a modern biomarker to assess cognitive functioning in HD patients. The data revealed a statistically significant difference in IGF-1 levels among all three groups (severe CI, moderate CI, and no CI) [19]. Furthermore, increased serum IGF-1 levels may lower the risk of developing dementia, as IGF-1 is involved in the removal of beta amyloid from the brain. As a result, it can be assigned a beneficial role in cognitive function improvement [20].

The next marker under consideration is fibroblast growth factor-23 (FGF-23), whose level is elevated in HD patients and is linked to left ventricular hypertrophy and increased mortality [21,22]. Furthermore, the presence of FGF-23 in the brain has been demonstrated $[23,24]$. In another study, elevated levels of FGF23 were linked to memory deterioration as measured by composite memory scores. This suggests that in HD patients, this marker may contribute to CI [25]. 


\subsection{Markers Related to Uremic Toxins}

Among uremic markers, serum uric acid (SUA) has been linked to CI. Some studies found that a higher level of SUA was associated with poorer cognitive function [26,27], while others found that it was beneficial $[28,29]$, which could be related to uric acid antioxidant and oxidant function in neurons [30]. A study on chronic hemodialysis patients found a negative correlation between SUA and MMSE scores $(r=-0.307, p=0.014)$, which was independent of clinical and demographic factors [31].

The next marker, indole-3-acetic acid (IAA), is a uremic solute that is protein-bound. IAA was found to be responsible for the activation of the AhR/p38MAPK/NF-B inflammatory pathway in human endothelial cells, which resulted in increased ROS production, stimulation of cyclooxygenase-2, and tissue factor expression [32]. It is also known that oxidative stress and nervous system inflammation contribute to neurodegeneration [33]. Furthermore, both studies [34,35] discovered a link between IAA and cognitive impairment in HD patients.

Another study used metabolic profiling to identify uremic metabolites associated with impaired executive function in two groups of patients receiving maintenance dialysis. Executive function impairment has been linked to four metabolites: prolyl-hydroxyproline, phenylacetylglutamine, 4-hydroxyphenylacetate, and hippurate [36].

Hyponatremia is another marker associated with CI in HD patients, according to the literature. However, it is not a common abnormality associated with renal failure. In this difficult patient population, it is more frequently associated with other comorbidities (e.g., heart failure, dementia disorders). Significant correlations were discovered between CI, depression symptoms, and serum sodium levels. Furthermore, such differences have been observed in hyponatraemia of any severity (moderate to severe) [37]. The following study discovered a link between impaired functional status and mild chronic hyponatremia [38]. One possible explanation is that uremia can cause neuronal damage, which can lead to cognitive decline and lower serum sodium levels in HD patients [39]. Another theory is that hyponatremia alters the amino acids in the brain [40], which may be related to cognitive function [41].

\subsection{Disorders Associated with ESRD}

Several studies have confirmed the importance of vitamin D in cognitive disorders (see Table 1). Patients with renal insufficiency are known to have low vitamin D levels. Furthermore, vitamin $\mathrm{D}$ has been shown to play a role in neuroprotection via glial cell-derived neurotrophic factor, nitric oxide synthase, and nerve growth factor. Vitamin D appears to promote neuron survival, increase antioxidant activity, improve oxidative stress-induced mitochondrial dysfunction, and reduce the effect of excitatory neurotoxins. Vitamin D also reduces amyloid precursor transcription, which prevents amyloid-beta accumulation. As a result, it is understood that a lack of Vitamin D reduces neurological function and thus the CI [42,43]. The first study found that patients with cognitive impairment were more likely to be African Americans, women, diabetics, and patients who have been on dialysis for a longer period of time. Higher levels of $25(\mathrm{OH}) \mathrm{D}$ correlated with results in executive function tests for each SD higher level of $25(\mathrm{OH}) \mathrm{D}$. In the case of memory assessment tests, there was no correlation [44].

Anemia is another factor to consider, as it increases the cerebral oxygen extraction fraction in HD patients and may impair cerebral vasodilator capacity [45]. Cognitive impairment is common in ESRD and is associated with poor outcomes, and anemia in these patients can lead to cerebral ischemia, cognitive impairment, and dementia [43]. The study confirms that anemia can cause CI in patients with HD. The first study found that anemia is linked to mild to moderate cognitive impairment in people with Parkinson's disease. The results of cognitive function tests improved as the hemoglobin level increased. Furthermore, blood flow increased in the middle cerebral artery (MCA). The greatest improvement was seen in stage $3(\mathrm{Hb} 11.5-12.5 \mathrm{~g} / \mathrm{dL}, 7.14-7.76 \mathrm{mmol} / \mathrm{L})$ compared to stage 2 ( $\mathrm{Hb} 10-11.5 \mathrm{~g} / \mathrm{dL}, 6.21-7.14 \mathrm{mmol} / \mathrm{L})$. In the case of MCA, Hb values of $11.5-12.5 \mathrm{~g} / \mathrm{dL}$ 
were associated with the greatest improvement in cognitive function and cerebral circulation in transcranial Doppler (TCD) testing [46]. Another retrospective study examined data from 43, 906 adult HD patients using Cox's hazard ratio and regression models. EPO supplementation was associated with a $39 \%$ lower risk of developing systemic dementia compared to patients who did not receive EPO supplementation. The risk of incurable dementia $(\mathrm{UnD})$ and vascular dementia $(\mathrm{VaD})$ was also lower in the EPO group. Patients who received both EPO and iron preparations reaped additional benefits [47].

\subsection{Cognitive Function and Systemic Cardiovascular Risk Factors}

Table 1 shows studies that link CI to cardiovascular risk factors. Many studies have found that pulse wave velocity (PWV) and ankle-brachial index (ABI) are important factors associated with cognitive impairment in dialysis patients (ABI). These parameters have been validated as tools for assessing arterial health as measured by arterial stiffness. Peripheral arterial disease (PAD) has been shown to increase the risk of both cardiovascular disease [48] and cognitive impairment in the general population [49]. The studies found suggest that such a relationship exists in the group of HD patients as well. The first scientific study found that having a high PWV or a low ABI is associated with poor cognitive function in HD patients [50]. Other studies [51] support the link between PWV and cognitive impairment in hemodialysis patients. Orthostatic pressure reduction is another cardiovascular factor linked to cognitive performance. According to research, there is a link between CKD and the impairment of orthostatic pressure stabilization, specifically the orthostatic systolic function [52,53]. It is well understood that impaired renal function reduces baroreceptor sensitivity and causes autonomic dysfunction, which increases the risk of orthostatic hypotension [54,55]. According to the findings of the study, an excessive reduction in orthostatic pressure in HD patients causes memory impairment [56]. The common carotid pulsation is an indicator of cerebral microvascular microangiopathy (CCAPI). Furthermore, studies show that CCAPI correlates with cognitive function in HD patients with no history of stroke or dementia [57]. Another factor to consider is left ventricular function. CKD increases the risk of developing left ventricular hypertrophy at a young age. In the early stages of HD, 70-80 percent of patients have left ventricular hypertrophy [58,59]. Furthermore, chronic hemodialysis reduces cerebral blood flow, which may exacerbate the effects of low LVEF [60]. According to research, a mildly reduced LVEF correlates with cognitive impairment [61].

\subsection{Fluctuations in Cerebral Blood Flow and Cognitive Function}

Table 1 summarizes findings from studies that link CI to abnormal cerebral blood flow. It has been proposed that hemodialysis causes brain damage. It is associated with recurrent hemodynamic changes, specifically a decrease in cerebral intradialytic perfusion. Dialysis factors such as ultrafiltration volume or intradialytic hypotension could be one cause of this phenomenon $[62,63]$. White matter hyperintensity $(\mathrm{WMH})$ is a validated marker of small vessel diseases and changes in brain structure [64]. The first of the studies presented examines the relationship between cognitive functions in HD patients and mean flow velocity in the cerebral arteries (MFV). The volume of ultrafiltrates has been linked to a decrease in MFV during HD. Furthermore, it was discovered that the decline in cognitive functions (executive functions, global functions, and verbal fluency) during dialysis was related to the decline in MFV. Furthermore, 73 HD patients were re-examined after a year. Reduced global and executive function in these patients was significantly related to the percentage of MFV decline and progression of WMH burden [65].

Another study used quantitative sensitivity mapping to assess the relationship between the results of neuropsychological tests and clinical factors with non-invasive assessment of changes in regional cerebral venous blood saturation $\left(\mathrm{rSO}_{2}\right)$ in $\mathrm{HD}$ patients (QSM). In $\mathrm{HD}$ patients, the $\mathrm{SO}_{2}$ of bilateral thalamocortical, cortical, internal and basal, septal, and basal veins was lower than in the healthy control group (HC). The Montreal Cognitive Assessment (MoCA) and Mini-Mental State Examination (MMSE) scores were both lower 
in $\mathrm{HD}$ patients, and the MoCA scores correlated with $\mathrm{SO}_{2}$ levels in the brain's left internal vein. Clinical parameters such as iron levels, hematocrit, blood pressure before and after dialysis, and glucose have been shown in studies to be independent risk factors for cerebral $\mathrm{rSO}_{2}$. According to research, cerebral $\mathrm{rSO}_{2}$ can be considered a risk factor for cognitive disorders [66]. Another two studies used the INVOS 5100c system to assess regional saturation of the frontal lobes. The first found that HD patients with cognitive impairment had lower $\mathrm{rSO}_{2}$ levels in the brain than patients with normal cognitive functions [67]. The second study found that changes in $\mathrm{rSO}_{2}$ levels in the brain are significantly related to hemoglobin levels, pulse rate, and serum albumin levels [68].

All of these studies indicate that a better understanding of the causes of cerebral ischemic stroke in HD patients could help to prevent cognitive decline in this population.

Table 1. Grouped markers and risk factors of cognitive impairment in hemodialysis patients.

\begin{tabular}{|c|c|c|c|}
\hline $\begin{array}{l}\text { Correlates/Surrogates of Cognitive } \\
\text { Impairment }\end{array}$ & $\begin{array}{c}\text { Studied } \\
\text { Population }\end{array}$ & $\begin{array}{l}\text { Cognitive Impairment } \\
\text { Assessment }\end{array}$ & Ref. \\
\hline \multicolumn{4}{|c|}{ Markers Related to the Inflammatory Process and Cell Damage } \\
\hline $\begin{array}{c}\text { Neurobiomarker S100 calcium binding protein B (S100B); S100B level was } \\
\text { independent predictor of CI (cut-off } \\
\text { values for predicting CI was } 36.1 \mathrm{pg} / \mathrm{mL})\end{array}$ & $30 \mathrm{HD}^{*}$ & MMSE & [6] \\
\hline $\begin{array}{l}\text { Bone turnover marker RANKL (Receptor activator of nuclear factor-kappa B } \\
\text { ligand) level linked with better cognitive function. MoCA ( } \beta=1.14,95 \% \text { CI } \\
0.17 \text { to } 2.11) \text { and CASI }(\beta=3.06,95 \% \text { CI } 0.24 \text { to } 5.88) \text {. }\end{array}$ & $\begin{array}{l}251 \mathrm{HD}^{*} \\
37 \mathrm{HC}^{* *}\end{array}$ & $\begin{array}{l}\text { MoCA scale } \\
\text { Cognitive Abilities Screening Instrument } \\
\text { (CASI) }\end{array}$ & [10] \\
\hline $\begin{array}{l}\text { Endothelium-related biomarkers: syndecan-1, intercellular adhesion } \\
\text { molecule-1 (ICAM-1), and angiopoietin-2 (AGPT2) correlated with better CI. }\end{array}$ & $216 \mathrm{HD}$ & $\begin{array}{l}\text { Cambridge Cognitive Examination } \\
\text { MMSE }\end{array}$ & [12] \\
\hline $\begin{array}{l}\text { Brain-derived neurotrophic factor (BDNF) and platelets count correlated with } \\
\text { cognitive test scores. }\end{array}$ & $\begin{array}{l}58 \mathrm{HD} \\
20 \mathrm{HC}\end{array}$ & $\begin{array}{c}\text { MMSE } \\
\text { MoCA scale }\end{array}$ & [13] \\
\hline $\begin{array}{l}\text { Insulin-like growth factor-1 (IGF-1) low levels is risk factor for severe CI } \\
\text { and dementia. }\end{array}$ & $93 \mathrm{HD}$ & MMSE & [19] \\
\hline $\begin{array}{l}\text { FGF-23 linked with worse performance on a composite memory score; FGF-23 } \\
\text { was independently associated with a lower memory score. }\end{array}$ & $263 \mathrm{HD}$ & $\begin{array}{c}\text { Wechsler Memory Scale-III, } \\
\text { Word List Learning Subtest, } \\
\text { Wechsler Adult Intelligence Scale-III, } \\
\text { Block Design and Digit Symbol-Coding } \\
\text { Subtests, Trail Making Tests A and B }\end{array}$ & [25] \\
\hline \multicolumn{4}{|l|}{ Uremic Toxins } \\
\hline $\begin{array}{l}\text { Uric acid level showed negative } \\
\text { correlation with MMSE score }(\mathrm{r}=-0.307, p=0.014) \text {. }\end{array}$ & $180 \mathrm{HD}$ & MMSE & [31] \\
\hline $\begin{array}{l}\text { Protein-bound uremic solute-indole-3-acetic acid (IAA) serum level was } \\
\text { associated with a poor MMSE }(\beta=-0.90) \text { and a poor CASI }(\beta=-3.29) \text {. }\end{array}$ & $230 \mathrm{HD}$ & $\begin{array}{l}\text { MMSE } \\
\text { MoCA } \\
\text { CASI }\end{array}$ & [34] \\
\hline $\begin{array}{l}\text { Circulating free indoxyl sulfate levels were negatively associated with the } \\
\text { MMSE scores }(\beta=-0.62) \text { and the CASI scores }(\beta=-1.97) \text {. }\end{array}$ & $260 \mathrm{HD}$ & $\begin{array}{l}\text { MMSE } \\
\text { CASI }\end{array}$ & [35] \\
\hline $\begin{array}{c}\text { 4-hydroxyphenylacetate }(\mathrm{RR}=1.16), \\
\text { hippurane }(\mathrm{RR}=1.24), \\
\text { phenylacetylglutamine }(\mathrm{RR}=1.39), \text { prolyl-hydroxyproline }(\mathrm{RR}=1.20) \text { showed } \\
\text { association with CI scores. }\end{array}$ & $\begin{array}{l}141 \mathrm{HD} \\
180 \mathrm{HC}\end{array}$ & $\begin{array}{l}\text { Trail Making Test Part B } \\
\text { Digit Symbol Substitution Test }\end{array}$ & [36] \\
\hline Hyponatremia correlated with symptoms of depression. & $200 \mathrm{HD}$ & $\begin{array}{l}\text { Patient Health Questionnaire } \\
\text { Perceived Deficit Questionnaire-5 }\end{array}$ & [37] \\
\hline $\begin{array}{l}\text { Plasma phosphorus level ( }>6 \mathrm{mg} / \mathrm{dL}, p=0.034) \text {, inadequate dialysis dose } \\
(\mathrm{Kt} / \mathrm{V}<1,2, p=0.023) \text { and hyponatremia }(\mathrm{Na}<135 \mathrm{mEq} / \mathrm{L}, p=0.001) \\
\text { infuenced poor } \\
\text { executive and functional status. }\end{array}$ & $56 \mathrm{HD}$ & $\begin{array}{l}\text { Modified Mini-Mental State (3MS) Trail } \\
\text { Making Test A and B }\end{array}$ & [38] \\
\hline \multicolumn{4}{|c|}{$\begin{array}{ll} & \text { Disorders Associated with ESRD } \\
\end{array}$} \\
\hline $\begin{array}{l}\text { Vitamin } \mathrm{D}-25(\mathrm{OH}) \mathrm{D} \text { levels correlated with executive functions }(\beta=0.16 \text {; } \\
\qquad p<0.05) \text { but no with memory assessment tests. }\end{array}$ & $255 \mathrm{HD}$ & $\begin{array}{l}\text { MMSE, Wechsler Memory Scale-III (WMS-III), } \\
\text { Word List Learning Subtest Wechsler Adult } \\
\text { Intelligence Scale-III (WAIS-III) Block Design } \\
\text { and Digit Symbol-Coding subtests } \\
\text { Trail Making Test A and B }\end{array}$ & [44] \\
\hline $\begin{array}{l}\text { Anemia correlated with } \mathrm{CI} \text { (increase in } \mathrm{Hb} \text { values improved cognitive } \\
\text { functions); improvement in } \mathrm{Hb}(p<0.05) \text { correlated with cerebral artery } \\
\text { blood flow. }\end{array}$ & $120 \mathrm{HD}$ & MMSE & [46] \\
\hline $\begin{array}{l}\text { Patients receiving EPO had a } 39 \% \text { lower risk of general dementia than those in } \\
\text { the non-EPO group. } \\
\text { The risk of dementia was further reduced in HD patients with EPO treatment in } \\
\text { combination with iron. }\end{array}$ & 43, $906 \mathrm{HD}$ & Clinical data & [47] \\
\hline
\end{tabular}


Table 1. Cont.

\begin{tabular}{|c|c|c|c|}
\hline $\begin{array}{c}\text { Correlates/Surrogates of Cognitive } \\
\text { Impairment }\end{array}$ & $\begin{array}{c}\text { Studied } \\
\text { Population }\end{array}$ & $\begin{array}{c}\text { Cognitive Impairment } \\
\text { Assessment }\end{array}$ & Ref. \\
\hline \multicolumn{4}{|c|}{ Systemic cardiovascular risk factors } \\
\hline $\begin{array}{l}\text { Ankle-brachial index ABI }<0.9 \text { showed association with the MoCA score } \\
(\beta=0.62, p=0.011) \text { and the CASI score }(\beta=1.43, p=0.026) \text {. } \\
\text { Arterial stiffness surrogate-baPWV showed negative correlation with CASI } \\
\qquad(\beta=-0.70, p=0.009) .\end{array}$ & $136 \mathrm{HD}$ & $\begin{array}{l}\text { MoCA } \\
\text { CASI }\end{array}$ & [50] \\
\hline $\begin{array}{l}\text { Pulse wave velocity (PWV) values were associated with worse MMSE scores } \\
(\beta=-0.36, p=0.001) \text {, and MiniCog scores }(\beta=-0.26, p=0.02) \text {. } \\
\text { PWV value was significantly associated with TMTA but not with TMTB. }\end{array}$ & 72 HD & $\begin{array}{c}\text { MMSE, } \\
\text { Part A (TMTA) and Part B (TMTB) } \\
\text { Mini-Cog Test }\end{array}$ & [51] \\
\hline $\begin{array}{c}\text { Maximum orthostatic systolic blood } \\
\text { pressure reduction was independently and negatively associated with short } \\
(\beta=-0.05, p=0.029) \text { and delayed }(\beta=-0.05, p=0.035) \text { recall memory in } \\
\text { dialysis patients but not in controls. }\end{array}$ & $\begin{array}{l}80 \mathrm{HD} \\
80 \mathrm{HC}\end{array}$ & $\begin{array}{c}\text { MoCA } \\
\text { Auditory Verbal Learning Test (AVLT) }\end{array}$ & [56] \\
\hline $\begin{array}{l}\text { Common carotid artery pulsation index (CCAPI) had an independent effect on } \\
\text { attention retention in HD patients }(\beta=-0.36, p=0.01) \text {. }\end{array}$ & $\begin{array}{l}37 \mathrm{HD} \\
18 \mathrm{HC}\end{array}$ & MoCA & [57] \\
\hline $\begin{array}{l}\text { Left ventricle function-LVEF showed } \\
\text { inverse association with cognitive } \\
\text { impairment }(\beta=0.87, p=0.022)\end{array}$ & $72 \mathrm{HD}$ & MMSE & [61] \\
\hline \multicolumn{4}{|c|}{ Fluctuations in cerebral blood flow } \\
\hline $\begin{array}{l}\text { Marker of ischaemic cerebral small-vessel disease: prevalence of white matter } \\
\text { hyperintensities (WMH) on magnetic } \\
\text { resonance imaging was significantly higher in HD patients than in the healthy } \\
\text { subjects }(p<0.01)\end{array}$ & $\begin{array}{l}179 \mathrm{HD} \\
58 \mathrm{HC}\end{array}$ & $\begin{array}{l}\text { WMH (white matter hyperintensities) on MRI } \\
\text { is known CI risk factor in the } \\
\text { general population }\end{array}$ & [64] \\
\hline $\begin{array}{l}\text { Cerebral arterial mean flow velocity (MFV) decline was correlated with the } \\
\text { intradialytic decline in cognitive } \\
\text { functions, including global functions, } \\
\text { executive functions, and verbal fluency } \\
\qquad(p<0.01) .\end{array}$ & $97 \mathrm{HD}$ & $\begin{array}{l}\text { National Institute of Neurologic Disorders and } \\
\text { Stroke-Canadian Stroke Network } \\
\text { Neuropsychological Battery }\end{array}$ & [65] \\
\hline $\begin{array}{c}\text { Reduced regional cerebral venous oxygen saturation }(\mathrm{SvO}) \text { of two bilateral } \\
\text { cortical, thalamic, septal, internal cerebral and } \\
\text { basal regions in HD patients was } \\
\text { significantly lower than in HC. }\end{array}$ & $\begin{array}{l}54 \mathrm{HD} \\
54 \mathrm{HC}\end{array}$ & $\begin{array}{l}\text { MMSE } \\
\text { MoCA }\end{array}$ & [66] \\
\hline $\begin{array}{l}\text { Cerebral exigenation (rSO2) values in HD patients was lower compared to } \\
\text { cognitively healthy people. The relation between rSO2 and MoCA score was } \\
\text { significant after adjustment for age and gender }(p=0.007) \text {. }\end{array}$ & $39 \mathrm{HD}$ & MoCA & [67] \\
\hline
\end{tabular}

${ }^{*}$ HD—group of hemodialysis patients, ${ }^{* *} \mathrm{HC}$ - group of healthy control patients, MMSE-Mini-Mental State Exam, MoCA-Montreal Cognitive Assessment.

\subsection{Other Unclassified Factors}

Table 2 shows additional socioeconomic and lifestyle factors. Higher levels of education are associated with lower risks of cognitive impairment and mortality in the general population. This relationship exists in the HD group as well. In this group of patients, educational level, post-dialysis blood pressure, and socioeconomic status are independent factors of CI. Another correlation that exists in both the HD group and the general population is a higher prevalence of $\mathrm{CI}$ in people who are depressed. The longer the hemodialysis vintage, the greater the risk of $\mathrm{CI}$ [69-72]. The following article discusses the connection between CI and sleep quality. A lower risk of $\mathrm{CI}$ is directly related to better sleep quality [73]. Physical activity is another important factor. The findings of this study suggest that encouraging dialysis patients to exercise may reduce their risk of developing CI [74]. 
Table 2. Other unclassified factors influencing cognitive functions.

\begin{tabular}{|c|c|c|c|}
\hline Factors & Studied Population & CI Measures & Ref. \\
\hline $\begin{array}{l}\text { Factors correlating with CI were identified: Educational } \\
\text { level (OR 2.234), spKt/V (OR 1.982), Post-dialysis diastolic } \\
\text { blood (OR 1.982). }\end{array}$ & $219 \mathrm{HD}^{*}$ & MoCA & [69] \\
\hline $\begin{array}{l}\text { Identified correlates: socio-economic status and global } \\
\text { cognition score }\left(\chi^{2}=81.13, \mathrm{df}=48, p=0.002\right) \text {, education } \\
\text { level and orientation }\left(\chi^{2}=29.78, \mathrm{df}=8, p=0.000\right) \text {, recall } \\
\left(\chi^{2}=31.7, \mathrm{df}=12, p=0.002\right) \text {. A negative correlation was } \\
\text { found between dialysis vintage }(\mathrm{r}=-0.411, p=0.003) \text {, } \\
\text { depression }(\mathrm{r}=-0.721, p<0.01) \text { and cognitive function. }\end{array}$ & $50 \mathrm{HD}$ & $\begin{array}{c}\text { MoCA } \\
\text { Patient Health } \\
\text { Questionnaire-9 (PHQ-9) }\end{array}$ & [70] \\
\hline $\begin{array}{l}\text { A positive correlations was found between cognitive } \\
\text { function and years of education }(\mathrm{r}=0.52, p \leq 0.001) \\
\text { dialysis vintage }(\mathrm{r}=0.26, p \leq 0.001)\end{array}$ & $99 \mathrm{HD}$ & $\begin{array}{c}\text { Addenbrooke's Cognitive } \\
\text { Examination-Revised (ACE-R) }\end{array}$ & [71] \\
\hline $\begin{array}{c}\text { Educational level (odd ratio }=0.564, p=0.031 \text { ), anemia } \\
\text { (odd ratio }=0.743 ; p=0.046 \text { ) } \\
\text { assiociated with cognitive functions. }\end{array}$ & $108 \mathrm{HD}$ & MMSE & [72] \\
\hline $\begin{array}{l}\text { Sleep quality (OR } 10.709 p=0.002) \\
\text { independently associated with CI. }\end{array}$ & $106 \mathrm{HD}$ & $\begin{array}{l}\text { British Columbia Cognitive } \\
\text { Complaints Inventory }\end{array}$ & [73] \\
\hline Less physically active patients assiociated with CI. & $102 \mathrm{HD}$ & MMSE & [74] \\
\hline
\end{tabular}

${ }^{*} \mathrm{HD}$-group of hemodialysis patients; MMSE-Mini-Mental State Exam, MoCA-Montreal Cognitive Assessment.

\section{Conclusions}

Many biomarkers that correlate with CI in HD patients show that the pathogenesis of these changes in this group of patients is very complicated. Furthermore, the majority of the presented relationships will need to be confirmed in future studies. More research is needed in this area to identify key risk factors. Then, knowing the primary causes can aid in the design of nonpharmacological intervention studies to reduce the risk of $\mathrm{CI}$ in HD patients.

The risk factors for $\mathrm{CI}$ can be divided into three groups based on the review: traditional risk factors (present in the general population), dialysis-related risk factors, and nontraditional risk factors that occur more frequently in the HD group. Age, education, sleep quality, and depression are all traditional risk factors (ABI 0.9). Among the HD-related factors are dialysis vintage, uremic toxins (SUA, serum IAA, free IS levels, 4-hydroxyphenylacetate, phenylacetylglutamine, hippurate, prolyl-hydroxyproline), and EPO treatment quality. The final group of risk factors includes nontraditional risk factors that are more common in ESRD and hemodialysis patients. This category includes markers related to the inflammatory process and cell damage (serum levels of S100B, RANKL, ICAM-1, AGPT2, syndecan-1 HR, BDNF, TNF, interleukin-6, PLT, IGF-1, IGFBP-3), FGF-23, anemia, 25(OH)D levels, cardiovascular risk factors (PWV, CCAPI, LVEF), mean flow velocity in the cerebral arteries, or changes in regional cerebral blood (see Figure 2). On this basis, it can be concluded that the methods for combating CI that work in the general population can also work in HD patients. However, there is a need to develop novel anti-CI strategies that target specific HD risk factors, such as modified hemodialysis parameters (continuous on-line blood pressure, UF, temperature, saturation monitoring). 


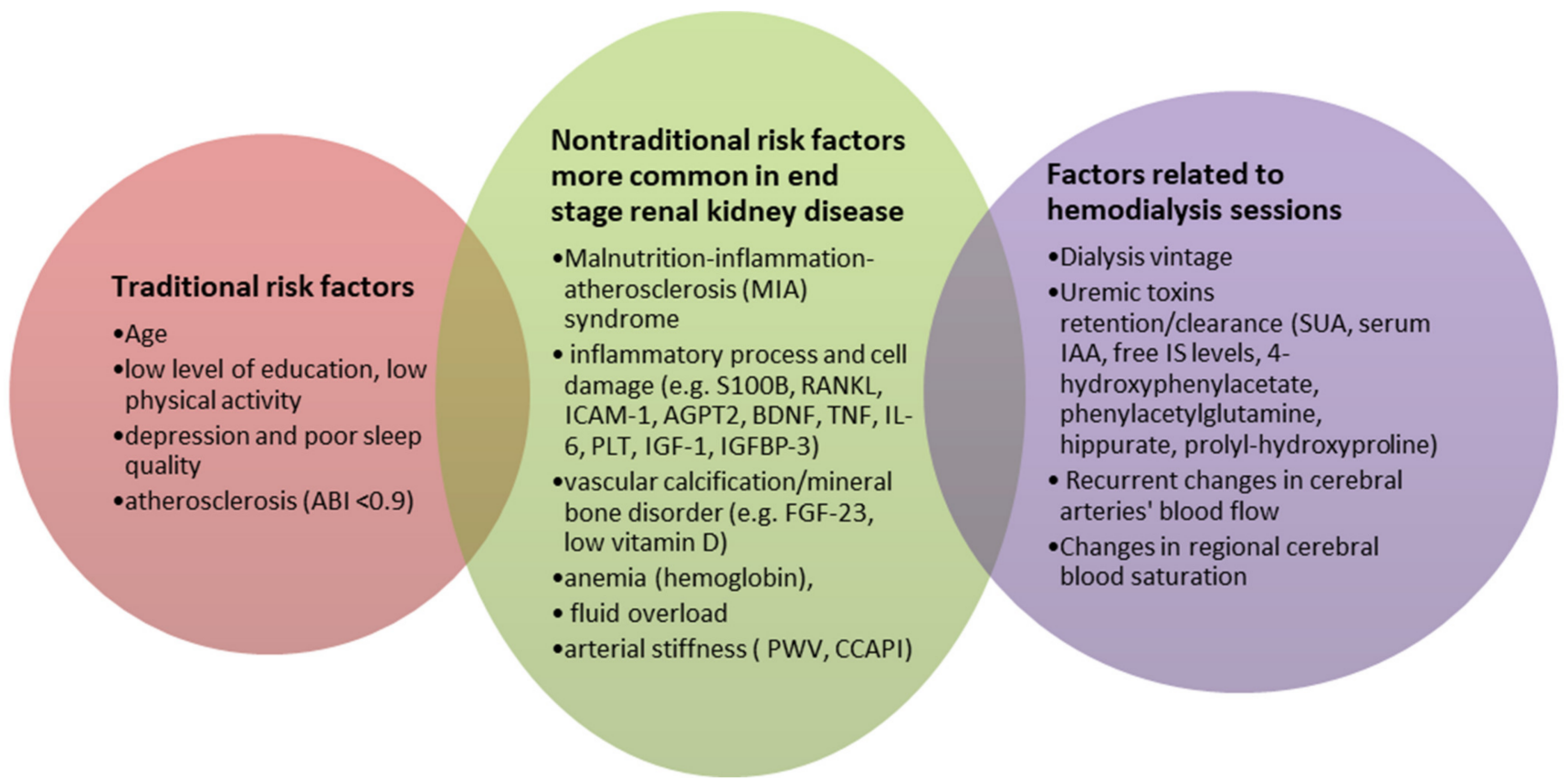

Figure 2. Risk factors for cognitive impairment in hemodialysis patients.

Author Contributions: Conceptualization, P.O. and M.K. (Mariusz Kusztal); methodology, P.O. and M.K. (Mariusz Kusztal); writing—original draft preparation, P.O., M.K. (Mariusz Kusztal), K.L. and T.G.; writing-review and editing, M.K. (Mariusz Kusztal), K.L., T.G. and M.K. (Magdalena Krajewska); supervision, M.K. (Mariusz Kusztal) and M.K. (Magdalena Krajewska). All authors have read and agreed to the published version of the manuscript.

Funding: Research financed by the young scientists project conducted by the Wroclaw Medical University, code: STM.C160.20.068.

Informed Consent Statement: Not applicable.

Conflicts of Interest: The authors declare no conflict of interest.

\section{References}

1. Johansen, K.L.; Chertow, G.M.; Foley, R.N.; Gilbertson, D.T.; Herzog, C.A.; Ishani, A.; Israni, A.K.; Ku, E.; Tamura, M.K.; Li, S.; et al. US Renal Data System 2020 Annual Data Report: Epidemiology of Kidney Disease in the United States. Am. J. Kidney Dis. 2021, 77, A7-A8. [CrossRef] [PubMed]

2. Schneider, S.M.; Malecki, A.K.; Müller, K.; Schönfeld, R.; Girndt, M.; Mohr, P.; Hiss, M.; Kielstein, H.; Jäger, K.; Kielstein, J.T. Effect of a single dialysis session on cognitive function in CKD5D patients: A prospective clinical study. Nephrol. Dial. Transplant. 2015, 30, 1551-1559. [CrossRef]

3. Pereira, A.A.; Weiner, D.E.; Scott, T.; Chandra, P.; Bluestein, R.; Griffith, J.; Sarnak, M.J. Subcortical cognitive impairment in dialysis patients. Hemodial. Int. 2007, 11, 309-314. [CrossRef]

4. Murray, A.M.; Knopman, D.S. Cognitive Impairment in CKD: No Longer an Occult Burden. Am. J. Kidney Dis. 2010, 56, 615-618. [CrossRef] [PubMed]

5. Macintyre, C.W. Recurrent circulatory stress: The dark side of dialysis. Semin. Dial. 2010, 23, 449-451. [CrossRef]

6. Park, B.S.; Lee, H.W.; Lee, Y.J.; Park, S.; Kim, Y.W.; Kim, S.E.; Kim, I.H.; Park, J.H.; Park, K.M. Serum S100B represents a biomarker for cognitive impairment in patients with end-stage renal disease. Clin. Neurol. Neurosurg. 2020, 195, 105902. [CrossRef]

7. Boyce, B.F.; Xing, L. Biology of RANK, RANKL, and osteoprotegerin. Arthritis Res. Ther. 2007, 9 (Suppl. S1), S1. [CrossRef]

8. Walsh, M.C.; Choi, Y. Biology of the RANKL-RANK-OPG system in immunity, bone, and beyond. Front. Immunol. 2014,5 , 511. [CrossRef] [PubMed]

9. Van Campenhout, A.; Golledge, J. Osteoprotegerin, vascular calcification and atherosclerosis. Atherosclerosis 2009, 204, 321-329. [CrossRef] [PubMed]

10. Wu, P.-H.; Lin, Y.-T.; Chen, C.-S.; Chiu, Y.-W.; Tsai, J.-C.; Kuo, P.-L.; Hsu, Y.-L.; Ljunggren, Ö.; Fellström, B.; Kuo, M.-C. Associations of Bone Turnover Markers with Cognitive Function in Patients Undergoing Hemodialysis. Dis. Markers 2020, $2020,8641749$. [CrossRef] 
11. Martins-Filho, R.K.; Zotin, M.C.; Rodrigues, G.; Pontes-Neto, O. Biomarkers Related to Endothelial Dysfunction and Vascular Cognitive Impairment: A Systematic Review. Dement. Geriatr. Cogn. Disord. 2020, 49, 365-374. [CrossRef] [PubMed]

12. De Medeiros, C.M.M.F.; Da Silva, B.R.D.; Costa, B.G.; Sartori, V.F.; Meneses, G.C.; Bezerra, G.F.; Martins, A.M.C.; Libório, A.B. Cognitive impairment, endothelial biomarkers and mortality in maintenance haemodialysis patients: A prospective cohort study. Nephrol. Dial. Transplant. 2020, 35, 1779-1785. [CrossRef] [PubMed]

13. Zhu, B.; Jin, L.-N.; Shen, J.-Q.; Liu, J.-F.; Jiang, R.-Y.; Yang, L.; Zhang, J.; Luo, A.-L.; Miao, L.-Y.; Yang, C. Differential expression of serum biomarkers in hemodialysis patients with mild cognitive decline: A prospective single-center cohort study. Sci. Rep. 2018, 8, 12250. [CrossRef] [PubMed]

14. Lu, B.; Nagappan, G.; Lu, Y. BDNF and Synaptic Plasticity, Cognitive Function, and Dysfunction. Inflammation 2014, 220, 223-250. [CrossRef]

15. Leal, G.; Comprido, D.; Duarte, C.B. BDNF-induced local protein synthesis and synaptic plasticity. Neuropharmacology 2014, 76, 639-656. [CrossRef] [PubMed]

16. Viana, J.L.; Kosmadakis, G.C.; Watson, E.L.; Bevington, A.; Feehally, J.; Bishop, N.C.; Smith, A.C. Evidence for Anti-Inflammatory Effects of Exercise in CKD. J. Am. Soc. Nephrol. 2014, 25, 2121-2130. [CrossRef]

17. Carlsson, A.C.; Carrero, J.-J.; Stenvinkel, P.; Bottai, M.; Barany, P.; Larsson, A.; Ärnlöv, J. Endostatin, Cathepsin S, and Cathepsin L, and Their Association with Inflammatory Markers and Mortality in Patients Undergoing Hemodialysis. Blood Purif. 2015, 39, 259-265. [CrossRef]

18. Norden, D.M.; Godbout, J.P. Review: Microglia of the aged brain: Primed to be activated and resistant to regulation. Neuropathol. Appl. Neurobiol. 2013, 39, 19-34. [CrossRef]

19. Prelevic, V.; Radunovic, D.; Antunovic, T.; Ratkovic, M.; Gligorovic-Bahranovic, N.; Gledovic, B.; Vujosevic, S.; Nedovic-Vukovic, M.; Basic-Jukic, N. Increased Serum Level of IGF-1 Correlates with Better Cognitive Status in End-Stage Renal Disease Patients Undergoing Hemodialysis. Ther. Apher. Dial. 2018, 22, 118-123. [CrossRef]

20. Kurella Tamura, M.; Larive, B.; Unruh, M.L.; Stokes, J.B.; Nissenson, A.; Mehta, R.L.; Chertow, G.M.; The Frequent Hemodialysis Network Trial Group. Prevalence and correlates of cognitive impairment in hemodialysis patients: The Frequent Hemodialysis Network trials. Clin. J. Am. Soc. Nephrol. 2010, 5, 1429-1438. [CrossRef] [PubMed]

21. Gutiérrez, O.M.; Januzzi, J.L.; Isakova, T.; Laliberte, K.; Smith, K.; Collerone, G.; Sarwar, A.; Hoffmann, U.; Coglianese, E.; Christenson, R.; et al. Fibroblast Growth Factor 23 and Left Ventricular Hypertrophy in Chronic Kidney Disease. Circulation 2009, 119, 2545-2552. [CrossRef] [PubMed]

22. Kirkpantur, A.; Balci, M.; Gurbuz, O.A.; Afsar, B.; Canbakan, B.; Akdemir, R.; Ayli, M.D. Serum fibroblast growth factor-23 (FGF-23) levels are independently associated with left ventricular mass and myocardial performance index in maintenance haemodialysis patients. Nephrol. Dial. Transplant. 2010, 26, 1346-1354. [CrossRef]

23. Yamashita, T.; Yoshioka, M.; Itoh, N. Identification of a Novel Fibroblast Growth Factor, FGF-23, Preferentially Expressed in the Ventrolateral Thalamic Nucleus of the Brain. Biochem. Biophys. Res. Commun. 2000, 277, 494-498. [CrossRef] [PubMed]

24. Liu, S.; Guo, R.; Simpson, L.G.; Xiao, Z.-S.; Burnham, C.E.; Quarles, L.D. Regulation of Fibroblastic Growth Factor 23 Expression but Not Degradation by PHEX. J. Biol. Chem. 2003, 278, 37419-37426. [CrossRef] [PubMed]

25. Drew, D.A.; Tighiouart, H.; Scott, T.M.; Lou, K.V.; Fan, L.; Shaffi, K.; Weiner, D.E.; Sarnak, M.J. FGF-23 and cognitive performance in hemodialysis patients. Hemodial. Int. 2014, 18, 78-86. [CrossRef] [PubMed]

26. Cervellati, C.; Romani, A.; Seripa, D.; Cremonini, E.; Bosi, C.; Magon, S.; Passaro, A.; Bergamini, C.M.; Pilotto, A.; Zuliani, G. Oxidative balance, homocysteine, and uric acid levels in older patients with Late Onset Alzheimer's Disease or Vascular Dementia J. Neurol. Sci. 2014, 337, 156-161. [CrossRef] [PubMed]

27. Cicero, A.F.G.; The Brisighella Heart Study Group; Desideri, G.; Grossi, G.; Urso, R.; Rosticci, M.; D’Addato, S.; Borghi, C. Serum uric acid and impaired cognitive function in a cohort of healthy young elderly: Data from the Brisighella Study. Intern. Emerg. Med. 2014, 10, 25-31. [CrossRef]

28. Al-Khateeb, E.; Althaher, A.; Al-Khateeb, M.; Al-Musawi, H.; Azzouqah, O.; Al-Shweiki, S.; Shafagoj, Y. Relation between Uric Acid and Alzheimer's Disease in Elderly Jordanians. J. Alzheimer's Dis. 2015, 44, 859-865. [CrossRef] [PubMed]

29. Beydoun, M.A.; Canas, J.-A.; Dore, G.A.; Beydoun, H.A.; Rostant, O.S.; Fanelli-Kuczmarski, M.T.; Evans, M.K.; Zonderman, A.B. Serum Uric Acid and Its Association with Longitudinal Cognitive Change Among Urban Adults. J. Alzheimer's Dis. 2016, 52, 1415-1430. [CrossRef]

30. Sautin, Y.Y.; Johnson, R.J. Uric Acid: The Oxidant-Antioxidant Paradox. Nucleosides Nucleotides Nucleic Acids 2008, 27, 608-619. [CrossRef]

31. Zhang, J.; Tang, L.; Hu, J.; Wang, Y.; Xu, Y. Uric acid is associated with cognitive impairment in the elderly patients receiving maintenance hemodialysis-A two-center study. Brain Behav. 2020, 10, e01542. [CrossRef] [PubMed]

32. Gondouin, B.; Cerini, C.; Dou, L.; Sallée, M.; Duval-Sabatier, A.; Pletinck, A.; Calaf, R.; Lacroix, R.; Jourde-Chiche, N.; Poitevin, S.; et al. Indolic uremic solutes increase tissue factor production in endothelial cells by the aryl hydrocarbon receptor pathway. Kidney Int. 2013, 84, 733-744. [CrossRef] [PubMed]

33. Hsieh, H.-L.; Yang, C.-M. Role of Redox Signaling in Neuroinflammation and Neurodegenerative Diseases. BioMed Res. Int. 2013, 2013, 484613. [CrossRef] [PubMed]

34. Lin, Y.-T.; Wu, P.-H.; Lee, H.-H.; Mubanga, M.; Chen, C.-S.; Kuo, M.-C.; Chiu, Y.-W.; Kuo, P.-L.; Hwang, S.-J. Indole-3 acetic acid increased risk of impaired cognitive function in patients receiving hemodialysis. NeuroToxicology 2019, 73, 85-91. [CrossRef] 
35. Lin, Y.-T.; Wu, P.-H.; Liang, S.-S.; Mubanga, M.; Yang, Y.-H.; Hsu, Y.-L.; Kuo, M.-C.; Hwang, S.-J.; Kuo, P.-L. Protein-bound uremic toxins are associated with cognitive function among patients undergoing maintenance hemodialysis. Sci. Rep. 2019, 9, 20388. [CrossRef]

36. Tamura, M.K.; Chertow, G.M.; Depner, T.A.; Nissenson, A.R.; Schiller, B.; Mehta, R.L.; Liu, S.; Sirich, T.L. Metabolic Profiling of Impaired Cognitive Function in Patients Receiving Dialysis. J. Am. Soc. Nephrol. 2016, 27, 3780-3787. [CrossRef]

37. Fan, S.; Lin, L.; Chen, V.C.; Hsieh, C.; Hsiao, H.; McIntyre, R.S.; Iacobucci, M.; Coles, A.S.; Tsai, D.; Weng, J.; et al. Effects of Lower Past-Year Serum Sodium and Hyponatremia on Depression Symptoms and Cognitive Impairments in Patients with Hemodialysis. Ther. Apher. Dial. 2020, 24, 169-177. [CrossRef]

38. Shavit, L.; Mikeladze, I.; Torem, C.; Slotki, I. Mild hyponatremia is associated with functional and cognitive decline in chronic hemodialysis patients. Clin. Nephrol. 2014, 82, 313-319. [CrossRef]

39. Zyada, F.; Makar, S.H.; Abdelrahman, S.M.; Labana, A.H. Assessment of cognitive functions in children on regular hemodialysis and after renal transplantation. Middle East Curr. Psychiatry 2017, 24, 128-133. [CrossRef]

40. Massieu, L.; Montiel, T.; Robles, G.; Quesada, O. Brain amino acids during hyponatremia in vivo: Clinical observations and ex-perimental studies. Neurochem. Res. 2004, 29, 73-81. [CrossRef]

41. van de Rest, O.; van der Zwaluw, N.L.; de Groot, L.C.P.G.M. Literature review on the role of dietary protein and amino acids in cognitive functioning and cognitive decline. Amino Acids 2013, 45, 1035-1045. [CrossRef] [PubMed]

42. Tamura, M.K.; Wadley, V.; Yaffe, K.; McClure, L.A.; Howard, G.; Go, R.; Allman, R.M.; Warnock, D.G.; McClellan, W. Kidney function and cognitive impairment in US adults: The Reasons for Geo-graphic and Racial Differences in Stroke (REGARDS) Study. Am. J. Kidney Dis. 2008, 52, 227-234. [CrossRef] [PubMed]

43. Murray, A.M.; Tupper, D.E.; Knopman, D.S.; Gilbertson, D.T.; Pederson, S.L.; Li, S.; Smith, G.; Hochhalter, A.K.; Collins, A.J.; Kane, R.L. Cognitive impairment in hemodialysis patients is common. Neurology 2006, 67, 216-223. [CrossRef]

44. Shaffi, K.; Tighiouart, H.; Scott, T.; Lou, K.; Drew, D.; Weiner, D.; Sarnak, M. Low 25-Hydroxyvitamin D Levels and Cognitive Impairment in Hemodialysis Patients. Clin. J. Am. Soc. Nephrol. 2013, 8, 979-986. [CrossRef]

45. Li, H.; Wang, S.-X. Intravenous Iron Sucrose in Chinese Hemodialysis Patients with Renal Anemia. Blood Purif. 2008, 26, 151-156. [CrossRef]

46. Shaker, A.M.; Mohamed, O.M.; Mohamed, M.F.; El-Khashaba, S.O. Impact of correction of anemia in end-stage renal disease patients on cerebral circulation and cognitive functions. Saudi J. Kidney Dis. Transplant. 2018, 29, 1333-1341. [CrossRef] [PubMed]

47. Hung, P.-H.; Yeh, C.-C.; Sung, F.-C.; Hsiao, C.-Y.; Muo, C.-H.; Hung, K.-Y.; Tsai, K.-J. Erythropoietin prevents dementia in hemodialysis patients: A nationwide population-based study. Aging 2019, 11, 6941-6950. [CrossRef]

48. Blacher, J.; Safar, M.E.; Guerin, A.P.; Pannier, B.; Marchais, S.J.; London, G.M. Aortic pulse wave velocity index and mortality in end-stage renal disease. Kidney Int. 2003, 63, 1852-1860. [CrossRef] [PubMed]

49. Guerchet, M.; Aboyans, V.; Nubukpo, P.; Lacroix, P.; Clément, J.P.; Preux, P.M. Ankle-brachial index as a marker of cognitive im-pairment and dementia in general population. A systematic review. Atherosclerosis 2011, 216, 251-257. [CrossRef]

50. Wu, P.-H.; Lin, Y.-T.; Wu, P.-Y.; Huang, J.-C.; Chen, S.-C.; Chang, J.-M.; Chen, H.-C. A Low Ankle-Brachial Index and High Brachial-Ankle Pulse Wave Velocity Are Associated with Poor Cognitive Function in Patients Undergoing Hemodialysis. Dis. Markers 2019, 2019, 9421352. [CrossRef]

51. Tasmoc, A.; Donciu, M.; Veisa, G.; Nistor, I.; Covic, A. Increased arterial stiffness predicts cognitive impairment in hemodialysis patients. Hemodial. Int. 2016, 20, 463-472. [CrossRef] [PubMed]

52. Fedorowski, A.; Stavenow, L.; Hedblad, B.; Berglund, G.; Nilsson, P.M.; Melander, O. Consequences of orthostatic blood pressure variability in middle-aged men (The Malmö Preventive Project). J. Hypertens. 2010, 28, 551-559. [CrossRef] [PubMed]

53. Canney, M.; O'Connell, M.D.L.; Sexton, D.J.; O'Leary, N.; Kenny, R.A.; Little, M.A.; O'Seaghdha, C.M. Graded Association Between Kidney Function and Impaired Orthostatic Blood Pressure Stabilization in Older Adults. J. Am. Hear. Assoc. 2017, 6, e005661. [CrossRef] [PubMed]

54. Johansson, M.; Gao, S.A.; Friberg, P.; Annerstedt, M.; Bergström, G.; Carlström, J.; Ivarsson, T.; Jensen, G.; Ljungman, S.; Mathillas, Ö.; et al. Reduced Baroreflex Effectiveness Index in Hypertensive Patients with Chronic Renal Failure. Am. J. Hypertens. 2005, 18, 995-1000. [CrossRef] [PubMed]

55. Jassal, S.V.; Douglas, J.F.; Stout, R.W. Prevalence of central autonomic neuropathy in elderly dialysis patients. Nephrol. Dial. Transplant. 1998, 13, 1702-1708. [CrossRef] [PubMed]

56. Liu, W.; Wang, L.; Huang, X.; Yuan, C.; Li, H.; Yang, J. Orthostatic blood pressure reduction as a possible explanation for memory deficits in dialysis patients. Hypertens. Res. 2019, 42, 1049-1056. [CrossRef]

57. Post, J.B.; Morin, K.G.; Handrakis, J.P.; Rivera, D.R.; Yen, C.; Sano, M.; Spungen, A.M. Cognition may be related to arterial pulsatility index in HD patients. Clin. Nephrol. 2014, 81, 313-319. [CrossRef]

58. Bossola, M.; Tazza, L.; Vulpio, C.; Luciani, G. Reviews: Is Regression of Left Ventricular Hypertrophy in Maintenance Hemodialysis Patients Possible? Semin. Dial. 2008, 21, 422-430. [CrossRef] [PubMed]

59. Middleton, R.J.; Parfrey, P.S.; Foley, R.N. Left Ventricular Hypertrophy in the Renal Patient. J. Am. Soc. Nephrol. 2001, 12, 1079-1084. [CrossRef] [PubMed]

60. Prohovnik, I.; Post, J.; Uribarri, J.; Lee, H.; Sandu, O.; Langhoff, E. Cerebrovascular effects of hemodialysis in chronic kidney disease. J. Cereb. Blood Flow Metab. 2007, 27, 1861-1869. [CrossRef] [PubMed] 
61. Bossola, M.; Laudisio, A.; Antocicco, M.; Tazza, L.; Colloca, G.; Tosato, M.; Zuccalà, G. Cognitive performance is associated with left ventricular function in older chronic hemodialysis patients: Result of a pilot study. Aging Clin. Exp. Res. 2014, 26, 445-451. [CrossRef]

62. MacEwen, C.; Sutherland, S.; Daly, J.; Pugh, C.; Tarassenko, L. Relationship between hypotension and cerebral ischemia during hemodialysis. J. Am. Soc. Nephrol. 2017, 28, 2511-2520. [CrossRef] [PubMed]

63. Polinder-Bos, H.A.; García, D.V.; Kuipers, J.; Elting, J.W.J.; Aries, M.J.; Krijnen, W.P.; Groen, H.; Willemsen, A.T.; Van Laar, P.J.; Strijkert, F.; et al. Hemodialysis Induces an Acute Decline in Cerebral Blood Flow in Elderly Patients. J. Am. Soc. Nephrol. 2018, 29, 1317-1325. [CrossRef]

64. Naganuma, T.; Takemoto, Y.; Shoji, T.; Shima, H.; Ishimura, E.; Okamura, M.; Nakatani, T. Factors associated with cerebral white matter hyperintensities in haemodialysis patients. Neurology 2012, 17, 561-568. [CrossRef] [PubMed]

65. Findlay, M.D.; Dawson, J.; Dickie, D.A.; Forbes, K.P.; McGlynn, D.; Quinn, T.; Mark, P. Investigating the Relationship between Cerebral Blood Flow and Cognitive Function in Hemodialysis Patients. J. Am. Soc. Nephrol. 2019, 30, 147-158. [CrossRef] [PubMed]

66. Chai, C.; Wang, H.; Chu, Z.; Li, J.; Qian, T.; Haacke, E.M.; Xia, S.; Shen, W. Reduced regional cerebral venous oxygen saturation is a risk factor for the cognitive impairment in hemodialysis patients: A quantitative susceptibility mapping study. Brain Imaging Behav. 2020, 14, 1339-1349. [CrossRef]

67. Kovarova, L.; Valerianova, A.; Kmentova, T.; Lachmanova, J.; Hladinova, Z.; Malik, J. Low Cerebral Oxygenation Is Associated with Cognitive Impairment in Chronic Hemodialysis Patients. Nephron 2018, 139, 113-119. [CrossRef] [PubMed]

68. Ito, K.; Ookawara, S.; Ueda, Y.; Miyazawa, H.; Uchida, T.; Kofuji, M.; Hayasaka, H.; Minato, S.; Kaneko, S.; Mutsuyoshi, Y.; et al. Cerebral oxygenation improvement is associated with hemoglobin increase after hemodialysis initiation. Int. J. Artif. Organs 2020, 43, 695-700. [CrossRef] [PubMed]

69. Lu, R.; Xu, C.; Li, Y.; Yu, L.; Shao, X.; Xie, K.; Gu, J.; Yu, Z.; Yan, Y.; Guan, Y.; et al. The Incidence Prognosis and Risk Factors of Cognitive Impairment in Maintenance Haemodialysis Patients. Blood Purif. 2018, 47, 101-108. [CrossRef] [PubMed]

70. Joseph, S.J.; Bhandari, S.; Dutta, S. Cognitive Impairment and its Correlates in Chronic Kidney Disease Patients Undergoing Haemodialysis. J. Evol. Med. Dent. Sci. 2019, 8, 2818-2822. [CrossRef] [PubMed]

71. Gesualdo, G.D.; Duarte, J.G.; Zazzetta, M.S.; Kusumota, L.; Say, K.G.; Pavarini, S.C.I.; Orlandi, F.D.S. Cognitive impairment of patients with chronic renal disease on hemodialysis and its relationship with sociodemographic and clinical characteristics. Dement. Neuropsychol. 2017, 11, 221-226. [CrossRef] [PubMed]

72. Fadili, W.; Al Adlouni, A.; Louhab, N.; Allah, M.H.; Kissani, N.; Laouad, I. Prevalence and risk factors of cognitive dysfunction in chronic hemodialysis patients. Aging Ment. Health 2013, 18, 207-211. [CrossRef]

73. Zubair, U.B.; Butt, B. Association of Quality of Sleep with Cognitive Decline Among the Patients of Chronic Kidney Disease Undergoing Haemodialysis. J. Ayub. Med. Coll. Abbottabad. 2017, 29, 619-622. [PubMed]

74. Stringuetta-Belik, F.; Shiraishi, F.G.; E Silva, V.R.O.; Barretti, P.; Caramori, J.D.S.C.T.; Bôas, P.J.F.V.; Martin, L.C.; Franco, R.J.D.S. Greater level of physical activity associated with better cognitive function in hemodialysis in end stage renal disease. J. Bras. Nefrol. 2012, 34, 378-386. [CrossRef] [PubMed] 